\title{
Southeast Asia in the age of jazz: Locating popular culture in the colonial Philippines and Indonesia
}

\author{
Peter Keppy
}

\begin{abstract}
Referencing insights from Cultural Studies and taking a jazz-age perspective, this essay aims to historicise and 'locate the popular' in colonial Indonesia and the Philippines. A new cultural era dawned in the 1920s urban hubs of Southeast Asia, associated with the creation of novel forms of vernacular literature, theatre, music and their consumption via the print press, gramophone, radio broadcasting and cinema. By investigating the complex relationship between the elusive phenomena of modernity, cosmopolitanism and nationalism as articulated by two pioneering artists active in commercial music and theatre, the social significance of popular culture is scrutinised.
\end{abstract}

The 1920s was a period of intensive cultural borrowing and experimentation. The inter-ethnic urbanites, particularly a newly emerging middle-class of professionals and officials in harbour cities like Manila, Cebu, Batavia, Surabaya and Singapore, took part in this process as both producers and consumers, enjoying theatre, literature, cinema and phonographic recordings. New forms of music, theatre, literature and fashion (dress, hairstyles) have, often implicitly, been associated with burgeoning popular culture and the interrelated upsurge of media technologies such as the gramophone, radio broadcasting, motion pictures and the print media. ${ }^{1}$

Peter Keppy is senior researcher at NIOD, Institute of War, Holocaust and Genocide Studies, Amsterdam. Correspondence in connection with this paper should be addressed to: p.keppy@niod. knaw.nl. I would like to thank the Netherlands Organization for Scientific Research (NWO) for its financial support for the project in which this article took shape: 'Articulating modernity: The making of popular music in 20th century Southeast Asia and the rise of new audiences' and The Royal Netherlands Institute of Southeast Asian and Caribbean Studies (KITLV) in Leiden, for hosting the project. I would also like to thank Bart Barendregt, Eveline Buchheim, Ariel Heryanto, Jaap Erkelens, Fritz Schenker, Henk Schulte Nordholt and the many participants of the Ninth International Conference on the Philippines (ICOPHIL), Michigan State University, East Lansing, 28-30 October 2012, for their comments on an earlier version of this essay. My gratitude also goes to the two anonymous referees for their productive comments. For shortfalls that remain I take full responsibility.

1 On 'Malay Opera' see Wan Abdul Kadir, Budaya popular dalam masyarakat Melayu bandaran (Kuala Lumpur: Dewan Bahasa dan Pustaka, 1988); Tan Sooi Beng, Bangsawan: A social and stylistic history of popular Malay opera (Singapore: Oxford University Press, 1993); Matthew Isaac Cohen, The Komedie Stamboel: Popular theatre in colonial Indonesia, 1983-1903 (Athens, OH: Ohio University Press, 2006); On Philippine vernacular theatre see Doreen G. Fernandez, 'Zarzuela to Sarswela: Indigenization and transformation', Philippine Studies 41 (1993): 320-43; Alfred W. McCoy, 'Zarzuela and welga: Vernacular drama and the growth of working-class consciousness, Iloilo City, Philippines, 
In this essay I aim to historicise and to 'locate the popular' in colonial Indonesia and the Philippines by investigating social meaning. Referencing insights from Cultural Studies I will link discussions on both colonies which previously have been treated in isolation. In addition, a comparison between the two colonies is mutually illuminating; another important reason to focus on Indonesia and the Philippines is the historical transnational connections and cultural flows which intensified during the jazz age.

In what can be considered as a response to the criticism of his influential book on nationalism, Imagined communities, Benedict Anderson states that ' $[. .$.$] the contrast$ between cosmopolitanism and nationalism is mistaken; it's actually conjoined.' ${ }^{2}$ This is the direction I wish to pursue in this essay. I will look at how modernity, cosmopolitanism and nationalism interlocked during the jazz age. A focus on this complex relationship mitigates the emphasis on modernity currently in studies on popular culture in colonial Indonesia and Malaya. By bringing such a relationship into an analysis of popular culture in the colonial Philippines, I will attempt to counter the idea of popular culture as socially meaningless entertainment.

To historicise popular culture, to capture its dynamics and to unveil its web of meanings, I will take a 'jazz age approach'. The jazz age is not a strictly demarcated epoch nor does this term mean that I will deal with jazz exclusively as a musical genre. It is intended as a trope to discuss social meaning. ${ }^{3}$ Jazz's hybrid European and Afro-American origins - the involvement of both Afro-American and white musicians who appealed to 'black' as well as a 'white' audiences - evoked debates and controversies in the late 1910s and 1920s. Jazz music, related social dances such as

1900-1932', in Society and the writer: Essays on literature in modern Asia, ed. Wang Gungwu, M. Guerrero and D. Marr (Canberra: The Australian National University, 1981), pp. 35-66. On SinoMalay literature in Indonesia, see Claudine Salmon, Literature in Malay by the Chinese of Indonesia: A provisional annotated bibliography (Paris: Editions de la Maison des Sciences de l'Homme, 1981). On newspapers in Malaya see Mark Emmanuel, 'Viewspapers: The Malay Press of the 1930s', Journal of Southeast Asian Studies 41, 1 (2010): 1-20. On Philippine literature see Bienvenido Lumbera and Cynthia Nograles Lumbera, Philippine literature: A history and anthology, rev. ed (Pasig City: Anvil, 1997); On the gramophone industry in colonial Malaya see Tan Sooi Beng, 'The 78rpm record industry in Malaya prior to World War II', Asian Music 1 (1996/97): 1-42; P. Yampolsky, 'The record industry in Indonesia/Malaysia/Singapore: The mechanics of an estimate of quantity. Part 1: 1903-1920', in The Lindström project: Contributions to the history of the record industry, vol. 3, ed. Pekka Gronow and Christiane Hofer (Wien: Gesellschaft für Historische Tonträger, 2011), pp. 181-93. On early Indonesian cinema see Misbach Y. Biran, Sejarah film 1900-1950: Bikin film di Jawa (Depok: Komunitas Bambu, 2009). On Philippine cinema see Bryan L. Yeatter, Cinema of the Philippines: A history and filmography, 1897-2005 (Jefferson, NC: McFarland \& Co, 2007); see also Nick Deocampo, Spanish influences on early cinema in the Philippines (Manila: Anvil, 2007). On radio broadcasting in colonial Indonesia see René Witte, De Indische radio-omroep: Overheidsbeleid en ontwikkeling 19231942 (Hilversum: Verloren, 1998); Takonai Susumu, Soeara NIROM and musical culture in colonial Indonesia (2007), trans. from Japanese by Ishibashi Makoto, Kyoto Review on Southeast Asia 8/9 (March/Oct 2007), http://kyotoreviewsea.org/Issue_8-9/Takonai_eng.html (last accessed 18 Sept. 2009). On Filipino radio broadcasting see Elizabeth L. Enriquez, Appropriation of colonial broadcasting: A history of early radio in the Philippines, 1922-1946 (Quezon City: University of the Philippine Press, 2009).

2 Cynthia Foo, 'Interview with Benedict Anderson', Invisible Culture 13 (2009): 4-21.

3 William H. Kenney, Chicago Jazz: A cultural history 1904-1930 (New York/Oxford: Oxford University Press, 1993), p. xiii; Nicholas M. Evans, Writing jazz: Race, nationalism and modern culture in the 1920s (New York/London: Garland, 2000), pp. 20-1. 
the Charleston and the Foxtrot, and its venues and audiences aroused interest beyond mere entertainment: jazz induced people to question and reconstruct the boundaries of race, class, national identity, gender and the modern. ${ }^{4}$

Richard Middleton, leaning on the work of Stuart Hall, forcefully argues not to take for granted the term 'popular music' as a self-explanatory category. We need to explicitly historicise it by contextualising what makes the popular, taking into account such key terms as process, relationship, transformation and contradiction.

What the term 'popular music' tries to do is put a finger on that space, that terrain, of contradiction - between 'imposed' and 'authentic', 'elite' and 'common', predominant and subordinate, then and now, theirs and ours [...] — and to organise it in particular ways. The relationships crossing this terrain take specific forms in specific societies, and must be analysed in that context. ${ }^{5}$

Modernity is loosely defined as a set of ideas and practices about the new, about innovation, progress and individualism. I like to use the term 'cultural cosmopolitanism' as defined by Helen Gilbert and Jacqueline Lo as 'an attitude or disposition characterised by openness to divergent cultural influences, as well as a practice of navigating across cultural boundaries'. ${ }^{6}$ I am also guided by Frederick Cooper's approach to modernity, namely that 'Finding a discourse of modernity could be a revealing demonstration.' This closely matches Middleton's approach in locating the popular.

Studies on vernacular literature as well as vernacular theatre under the generic name of Malay opera in colonial Indonesia and Malaya offer sufficient evidence for the type of discourses pinpointed by Cooper and Middleton. Theatre and literature not only stood for modernity, they equally offered people a vehicle to vent their anxieties about it. ${ }^{8}$

In contrast to studies on colonial Indonesia and Malaya, locating popular culture within a discourse on modernity has only rarely been a line of inquiry in studies on the popular culture of colonial Philippines. Writer Nick Joaquin, the Philippines' unofficial chronicler of popular culture, did see a 'pop era' emerge in the

4 For a brief discussion of relatively recent and social issue-driven studies on jazz and the jazz age in America, see John R. Gennari, 'Recovering the "noisy lostness": History in the age of jazz', Journal of Urban History 24, 2 (1998): 226-34. A good example of this social issue-driven historical approach in an Asian context is Andrew F. Jones's Yellow music: Media culture and colonial modernity in the Chinese jazz age (Durham/London: Duke University Press, 2001).

5 Richard Middleton, 'Articulating musical meaning/re-constructing musical history/locating the "popular"', Popular Music 5 (1985): 5.

6 Helen Gilbert and Jacqueline Lo, ed., Performance and cosmopolitics: Cross-cultural transaction in Australasia (New York: Palgrave MacMillan, 2007), p. 26.

7 Frederick Cooper, Colonialism in question: Theory, knowledge, history (Berkeley: University of California Press, 2005), pp. 130-1. I thus avoid speaking of 'colonial modernity' in the way that, for instance, Jones does in Yellow music, pp. 7-10.

8 Jan van der Putten, 'Negotiating the Great Depression: The rise of popular culture and consumerism in early-1930s Malaya', JSEAS 41, 1 (2010): 21-45; Doris Jedamski, '.. and then the lights went out and it was pitch-dark': From stamboel to tonil theatre and the transformation of perceptions', South East Asia Research 16, 3 (2008): 481-511; Laurie J. Sears, 'Modernity and decadence in fin-de siècle fiction of the Dutch Empire', Indonesia 90 (2010): 97-124; Elizabeth Chandra, 'Women and modernity: Reading the femme fatale in early twentieth-century Indies novels', Indonesia 92 (2011): 1-26. 
Philippines' American period and linked it to modern mass consumption. ${ }^{9}$ It should be noted that one would search in vain for a comparable chronicler of popular culture in colonial Indonesia. It is Joaquin's image of the 'pop era', strongly associated with American consumer practices and products - from smoking distinct brands of cigarettes to listening to the radio - that appears to have made a lasting impression on those engaged with cultural expressions and media during the American period in the Philippines. While Joaquin should be credited for putting popular culture on the historian's agenda, his assumptions remained very much implicit. He tended to equate popular culture in the Philippines with entertainment void of social content, i.e. leisure as an end in itself. This perspective comes very close to the 'consumerist escapism' angle, one that emphasises the workings of the cultural industry as manipulative and exploitative, spurring commodification and mass consumption, a theory dating back to the 1930s and developed by the Frankfurt School, pioneered by Theodor W. Adorno.

Joaquin's Manila-centred historiography and his implicit cultural juxtaposition or cultural tension of Anglo-Saxonism (Sajonista) versus a Filipinised-Hispanic cultural legacy (Hispanismo) have been generally accepted. ${ }^{10}$ Doreen Fernandez, authority in the field of Spanish and vernacular theatre in the Philippines, likewise emphasises mass consumption, and her assumptions are similarly implicit. In contrast to Joaquin's infectious thrill with the dynamics of pop culture in relation to the American period, Fernandez takes an opposite moral position, emphasising cultural apathy and decline:

There is the fact that the onslaught of American entertainment forces came into a receptive vacuum. [....] The various folk cultures were so different from the popular forms that came in with American life and culture that there was no real competition so that pop music, radio, and film practically had the field for themselves, without having to fight the 'kundiman' or the 'zarzuela' [....

When the local cultural industries [....] were eventually formed they simply developed from the American pioneers or copied their systems. They offered to no one that there might be a need for rethinking and restructuring these forms to suit Philippine needs and conditions. ${ }^{11}$

There is no need to reopen this discussion about the (alleged) manipulative role of the cultural industry and 'escape consumerism' here. ${ }^{12}$ The point is that scholars who

9 Nick Joaquin, 'Pop culture: The American Years', in Filipino heritage: The making of a nation, vol. 9, ed. Alfredo R. Roces (Manila: Lahing Pilipino, 1978): 2732-44; Nick Joaquin, Manila, my Manila: A history for the young (Manila: Bookmark, 1990), pp. 161, 167.

10 See, for example, Deocampo, Spanish influences, pp. xiv, 4, 14-19. Cristina Evangelista Torres echoes Joaquin in The Americanization of Manila 1898-1921 (Quezon City: University of the Philippines Press, 2010), pp. 179-80.

11 Doreen G. Fernandez, 'Philippine-American cultural interaction', Crossroads: An Interdisciplinary Journal of Southeast Asian Studies 1, 1 (1983), http://www.jstor.org/stable/40860163 (last accessed 15 Nov. 2012). The same assumptions are reiterated by Fernandez in her 'Mass culture and cultural policy: The Philippine experience', Philippine Studies 37 (1989): 488-502.

12 In fact neither the Frankfurt School nor Cultural Studies seem to have played a role whatsoever in discussions on popular culture in a Philippine colonial context. On 'escape consumerism' see Middleton, 'Articulating musical meaning', p. 11. For a brief but insightful critique of the political-economy approach of the Frankfurt School see John Storey, Cultural consumption and everyday life (London: 
study popular culture during the Philippine American period have been implicitly moralising and have only barely taken advantage of the theoretical armory, particularly as developed by the social sciences. ${ }^{13} \mathrm{~A}$ focus on the relationship between modernity, cosmopolitanism and nationalism might be a starting point for a new social issue-driven historiography of popular culture in Southeast Asia.

The 'trinity' of modernity, cosmopolitanism and nationalism was, obviously, unstable, even strained, in both the colonial Philippines and Indonesia due to shifts in their respective socioeconomic and political environments. From 1907, the United States granted Filipinos legislative and executive powers with the establishment of a Philippine Assembly, allowing Filipinos significant input into the administration of their own affairs. At the same time, the American promise of what turned out to be an indeterminate prospect of independence led to intricate political manoeuvres by the Filipino political elite and divisions within society at large uncertain as to whether, when and under which conditions independence would become feasible. ${ }^{14}$ This period can be summarised as one in which Filipinos moved through gradual acceptance of American rule to quiescence, and it contrasts starkly with the early days of the American period marked as it was by subversion and cultural resistance. ${ }^{15}$ This situation was very different from that in the Netherlands East Indies. The Dutch had no intention whatsoever of granting Indonesians legislative powers or executive authority, let alone autonomy or independence. The Dutch had created a legal system emphasising racial difference and related privileges in matters of government administration, education, the economy and the administration of justice. This institutionalised discrimination was particularly disadvantageous for native Indonesians and a main factor in enhancing ethnic polarisation and tension. The group legally classified as Europeans, including many Eurasians, held the privilege of ruling the colony. By the 1920s Dutch repression of the burgeoning Indonesian independence movement, which since the 1910s had demanded political, legal and social emancipation, had become firm colonial policy. ${ }^{16}$

Arnold, 1999), pp. 18-23, 31-2. For a sophisticated reappraisal of Adorno's thoughts on consumption, see Matt Hills, Fan cultures (New York: Routledge, 2002), pp. 31-5.

13 Although he shows little historical inclination himself, sociologist Ricardo G. Abad offers three theoretical perspectives for a cultural history of colonial Philippines: a brief overview from a Gramscian (neo-Marxist) perspective, with similarities to the political-economy approach of the Frankfurt School; a conflict studies view of 'popular culture' as an arena in which meaning is contested; and interpretative theories that seek to show how people perceive reality rather than that they are necessarily being manipulated by the culture industry. R.G. Abad, 'Sociological perspectives in the study of Philippine popular culture', in Reading popular culture, ed. Soledad S. Reyes (Quezon City: Office of Research and Publications Ateneo de Manila University, 1991), pp. 11-23.

14 Frank H. Golay, Face of empire: United States-Philippines relations 1898-1946 (Madison: Center for Southeast Asian Studies, University of Wisconsin-Madison Monograph no. 14. 1998); Michael Cullinane, Ilustrado politics: Filipino elite responses to American rule, 1898-1908 (Quezon City: Ateneo de Manila University Press, 2003).

15 On this cultural resistance through literature see Lumbera and Lumbera, Philippine Literature, pp. 87-91; On theatre as cultural vehicle of anti-American resistance see Tomas C. Hernandez, The emergence of modern drama in the Philippines (1898-1912) (Honolulu: University of Hawai'i, 1976), pp. 90169. Hernandez explicitly links the Filipinised Spanish theatrical genre sarswela to modernity and remains the only one to have done so.

16 Takashi Shiraishi, An age in motion: Popular radicalism in Java, 1912-1926 (Ithaca: Cornell University Press, 1990). 
It is against these, albeit differential, political and social backgrounds that I attempt to locate the popular and explore its social meanings. This is largely unexplored terrain, particularly in the case of colonial Indonesia. A comparison is helpful to assess the relative significance of cosmopolitanism, modernity and nationalism, delineating more sharply struggles, contradictions and ambivalence in the viewing of popular culture in two different colonial contexts. To concretise these elements I have chosen to focus on two individuals and their associates who are generally considered to have changed the face of popular culture in Southeast Asia in the twenties, but who have received surprisingly little scholarly attention: Filipino musician, composer and vaudeville impresario Luis F. Borromeo, and the Malay opera singer-actress Miss Riboet. They and their associates pioneered popular culture by innovating theatre and music, and illustrate the main issues addressed above. In the following three sections I will start with vaudevillian Borromeo, and look into the early stages of his professional career, the content of his cultural products (vaudeville shows and music) and his collaborative efforts. The ensuing section on Miss Riboet follows a similar thematic pattern. In the final section I reconnect my findings to the above discussion on popular culture.

\section{Borromeo Lou: Ilustrado going vodavil}

In July 1921, local bilingual newspaper Nueva Fuerza published in Cebu City, in the Visayan Islands, the third largest port city in the Philippines after Manila and Iloilo, announced the debut at the city's Oriente Theatre of 'Mr. Luis Borromeo, the famous Cebuano pianist who has toured the entire America, [....] This man famous for his great ability known as "King of Jazz" is one of the knowledgeable Cebuano artists who is the scion of the prestigious family of the Borromeos [....]'. ${ }^{17}$ Borromeo had returned from the United States that same year. He had been working as a pianist for the largest vaudeville theatre alliance in America, the Orpheum and Keith-Albee vaudeville circuits, which since the beginning of the twentieth century virtually monopolised the American vaudeville industry. ${ }^{18}$

The Borromeo family was indeed 'prestigious' in terms of social status and wealth. They belonged to the urban merchant and landholding elite of Cebu with origins in the seventeenth-century Chinese and Chinese-mestizo community of Parian, Cebu City. ${ }^{19}$ Luis was born in Cebu somewhere between 1879 and 1884 and educated according to the standards of the Hispanised Filipino provincial elites. ${ }^{20}$ Although he was fluent in vernacular Cebuano, Spanish was spoken at home. After studying in

17 Nueva Fuerza, 9 July 1921, 16 July 1921. I am indebted to director Hope Yu and the library staff of the Cebuano Study Center of San Carlos University, Cebu City, for giving me access to original copies of Nueva Fuerza amidst a transfer of the centre and its collection to a new building in February 2012.

18 Arthur F. Wertheim, Vaudeville wars: How the Keith-Albee and Orpheum circuits controlled the bigtime and its performers (New York: Palgrave MacMillan, 2006).

19 Michael Cullinane, 'The changing nature of the Cebu urban elite in the 19th century', in Philippine social history, ed. Alfred W. McCoy and Ed. C. de Jesus (Quezon City: Ateneo de Manila University Press, 1982), pp. 257-62.

20 As the birth registers of the Church in Cebu were destroyed during the Second World War and the remaining family was unable to confirm the dates it is impossible to determine Luis' date of birth and death with certainty. 
Cebu he was sent to further his studies — on commerce and trade — in Manila. ${ }^{21} \mathrm{His}$ father and first music tutor was a music teacher in Cebu and Manila, composer of religious music, and organist for Cebu's Cathedral and San Agustin Church. ${ }^{22}$ His mother was a Chinese-mestiza from the wealthy Cebuano Veloso family. She was active in a local Catholic religious association (cofradia) devoted to the patron saint Nuestra Señora del Rosario. ${ }^{23}$ The religiosity, educational standards and wealth of the Borromeo family were three mutually influential forces enhancing their relatively high social status within Cebuano society.

During the nineteenth century members of the larger Borromeo family moved into the expanding colonial bureaucracy in the Visayan Islands and in the administrative and political centre in Manila as high-ranking government officials. Many also successfully moved into white-collar professions as lawyers, priests, medical doctors, and music teachers. Eventually some, like Luis and his cousin Florentino, also entered into the burgeoning entertainment industry in the late 1910 s. $^{24}$ In brief, the Borromeos could be ranked among the ilustrados, 'a small segment of the indigenous elite that came to be recognised for their intelligence and educational attainment.' ${ }^{25}$ The violent regime change from Spanish to American rule between 1896 and 1903 appears to have had little negative effect on the Cebuano economic elite. For them, the revolution and the ensuing era which came to be known as the American period opened up new opportunities and brought them greater economic and political power that went beyond the Visayas into the political centre, Manila.

According to an interview given in 1921 to the Manila newspaper the Philippine Free Press, Luis had left the Philippines to visit the 1915 Panama-Pacific International Exposition in San Francisco. This journey changed his life. Borromeo's piano playing at a party somewhere in San Francisco caught the attention of a woman. Impressed by his songs and performance she introduced him to people working for the Keith \& Albee and Orpheum vaudeville companies. They were equally impressed. For the next six years, from 1915 into 1921, Luis, as a pianist using the Anglicised stage name of Borromeo Lou, toured coast to coast with the large chain of Orpheum and Keith \& Albee-owned theatres.

Luis returned to the Philippines in 1921 to make his debut in Cebu, followed by Iloilo and Manila's Grand Opera House. At this particular time he announced his shows not as vaudeville but as a 'Review of the evolution of the classical Jazz Music, Operatic and Classical Song' ${ }^{26}$ This was basically a concert in which various artists staged an eclectic musical program, including Philippine music (kundiman), opera, 'jazz' (this included a precursor of jazz and also its Afro-American origins,

21 His brothers went to Spain and later the United States to further their studies. I thank Michael Cullinane and Vincent, John and Jack Borromeo for sharing their data on the Borromeo genealogy with me.

22 The Agustin Church, currently known as the Basilica, is the home of the shrine of the Holy Child, Santo Niño, and a major pilgrimage site in the Philippines.

23 Nueva Fuerza, 14 Oct. 1915.

24 Unlike Luis, Florentino combined his activities as playwright for theatre and cinema in the 1920s and 1930s with official positions in the local administration of Cebu.

25 Cullinane, Ilustrado politics, p. 2.

26 Nueva Fuerza, 19 July 1921. 
the syncopated style of ragtime) and dance. ${ }^{27}$ It is from 1922 that Borromeo started to transform his musical shows into an even more eclectic playbill of short plays, music and dance that came closer to American and European vaudeville, yet with a distinct local tinge, as I will show later on. He himself started to use the term vaudeville during this period. Due to Borromeo's frequent performances in the capital and advertisements in the Manila Times, the term vaudeville and particularly its Hispano-Filipino corruption, vodavil, gained wider currency. While Borromeo has been credited for bringing American-style vaudeville to the Islands, there are strong indications that between the late nineteenth century and the 1910s a handful of prominent Manila-based Filipino actors active in the Spanish and the vernacular zarzuela theatre were already in the process of developing vaudeville-type shows. ${ }^{28}$ In the 1920s they would link up with Borromeo, and they were as much responsible for creating a Filipinised form of this particular form of theatre as their Cebuano colleague. For example, Eliseo Carvajal, son of renowned comedian José Carvajal, would straddle the gap between zarzuela and vaudeville and develop from a comedian and musician into a vaudeville playwright. ${ }^{29}$

\section{Cebuano Cosmopatriot}

Two-and-a-half years after his first appearance in Manila, Luis performed weekly with his vaudeville company 'Borromeo Follies of 1924' at the Olympic Stadium in the capital. His company was also regularly invited to perform at the private parties of Manila's new political and economic elite and the company toured the provinces extensively. ${ }^{30}$ Since 1922, however, the Stadium had become Borromeo's permanent venue in Manila due to his association with Frank Churchill and Eddie Tait, co-owners of the Stadium and boxing promoters. This connection explains the high frequency of boxing training stunts in Borromeo's vaudeville shows in the 1920 s, a way to advertise the weekly boxing bouts held at the Stadium. A similar strategy was pursued by the cinematic theatres in Manila, which combined film screenings

27 The kundiman genre is a hybrid of a precolonial music and literary tradition that merged with Hispano music related to the Cuban habanera and Argentinian tango.

28 Members of the Carvajal and Davila families in Manila were among these pioneers of Filipino vaudeville and at the core of an artistic network from which later theatre groups, including vaudeville companies, would emerge. In his novel Noli me tangere published in 1887, José Rizal mentions a comedy troupe from Tondo, Manila, including the actor 'Carvajal', which transformed the vernacular comedia theatre; Jose P. Rizal, Noli me tangere, trans. into English by Ma. Soledad Lacson-Locsin (Makati City: Bookmark), pp. 234-5. Rizal (p. 253) also refers to a religious celebration on which occasion a 'comic-mimic-lyrical-choreographic-dramatic presentation' was staged that appears to have contained ingredients of what was later defined as vaudeville. On the Carvajal family see Manuel Artigas y Cuerva, 'Teatro y artistas Filipinos' (manuscript, c. 1911; National Library of the Philippines).

29 Manila Times, 8 Mar. 1920; Manila Times, 2 Sept. 1925.

30 For example, Borromeo and his troupe performed at a party of the Philippine Columbian Association, held at Pasay Beach (Manila Times, 30 Sept. 1921). This was an association of Filipinos who had attended American universities, in sum an ilustrado organisation. Several board members held high offices in the Philippine government or could be counted among Manila's elite. This included Manuel Quezon, Jorge B. Vargas and the Governor-General of the Philippine Islands, Francis Burton Harrison. C.W. Rosenstock, Rosenstock's Manila City Directory 1924-1925 (Manila, 1925), p. 179. 
with vaudeville shows to attract spectators. ${ }^{31}$ The name 'Follies' reveals another of Borromeo's American sources of inspiration, The Ziegfield Follies, the Broadway revue show company that stormed New York audiences between 1915 and 1920.

More significant than boxing or the Ziegfield Follies, was the social content and artistic collaboration that was the basis for the October 1924 vaudeville show. It shows a transformation and process of 'localisation', or Filipinisation, of vaudeville. Borromeo had developed from a musician-composer into a vaudeville impresario and stage director. He composed music as well as the playbills, recruited new talent across the Philippines, directed the shows and conducted his orchestra. To make the playbills novel and innovative he actively sought artistic collaboration with playwrights in the vernacular and Spanish theatres, and with novelists, poets, composers and dancers. This was a strategy he used throughout his career. The October 1924 playbill is instructive. Borromeo had linked up with Clifford Adams, an American jazz pianist and leader of the Santa Ana Cabaret Orchestra and with Ruperto S. Cristobal, a Tagalog writer of note. The Santa Ana Cabaret (est. 1908) was Manila's biggest and most prestigious dance hall and was frequented by patrons from all walks of life. By the late 1910s the dance halls had become the subject of heated debates on morality, gender and social evils. In 1917 Cristobal published Ang bulaklak kabaret (Flower of the cabaret), a Tagalog novel on a bailerina, a professional female cabaret dancer, who offered male customers her dancing services for a small fee. Borromeo's October 1924 vaudeville playbill included a Tagalog comedy co-written with Cristobal: 'Maligo Tayo an Pasay!! Ika-apat na banagi ng Komediang Tagalog' (Let's take a bath in Pasay. A four act Tagalog Comedy). ${ }^{32}$

By 1924, the inclusion of comedies as well as short plays had become a permanent feature of Borromeo's shows. This demonstrates how vaudeville had evolved from a classy musical review in Cebu in 1921 into an eclectic Filipinised format in which drama, music, and dance were often united in a single show with at its core a short play, around which other acts, from acrobatics to boxing, were arranged. ${ }^{33}$ Moreover, we can observe a shift to social-issue-driven content, something generally believed to have been conspicuously missing in vodavil and at odds with the popular 'happy-go-lucky' image of this theatrical genre. Although we are handicapped by the lack of scripts or even reviews of 'Let's take a bath in Pasay!', the advertisement offers some clues to 'decode' the meaning of the play's title and characters and thus the social issues at stake. The play seemed to have been a comedy addressing the issue of modernity and the debates it evoked.

In the late 1910s and early 1920s, due to stringent official regulations on the dance halls and closure of the red-light district Gardenia in Manila proper, the city of Pasay, south of Manila, became a relatively safe haven for Manila's entertainment

31 In spite of Deocampo's claim (Spanish influence, p. 179) that by 1912 films were no longer combined with theatre, vaudeville shows and cinema from the early 1920s into the 1930s were inseparable twins. It is in the 1930s that a separation between the two occurred.

32 I thank Richie and Cherry Quirino for the translation from Tagalog and Karl Poblador for assisting me in accessing Philippine serials.

33 The program included Miss Pacita Corrales who sang 'My Bamboo Girls', presented as 'tango foxtrot' and possibly composed by Borromeo. The show also included a ten-minute exhibition by Grappler Nelson, a catch-as-can wrestler, with Corregidor Middleweight boxer George Slade, no doubt an American soldier stationed at the military base of Corregidor Island in Manila Bay. 
industry. Expansion of cabarets in Manila was halted and the existing dance halls were frequently policed, especially targeting minors and bailerinas or their male customers. Some of the entertainment entrepreneurs and their clientele had moved outside the city borders into neighbouring municipalities such as Makati, Pasig and Pasay, where local authorities observed regulations less strictly. The restrictive measures in Manila city were the outcome of a powerful alliance and political lobby of conservative politicians-cum-municipal board members, senators and representatives of the Catholic Church who considered the dance halls and prostitution social evils. ${ }^{34}$ These moralists portrayed bailerinas and prostitutes as poor uneducated provincial girls who fell victim to the desires of (often young) males. These patrons, it was said, spent their parent's monthly allowances-cum-student fees or their meagre professional salaries on liquor and hiring females for a dance or sexual services. The argument went that bailerinas and dance halls kept young men from their studies and work, leading them into unproductivity and debt; the female dancers, in turn, were being kept from their duties as women and wives. Prostitution was also seen as a health problem, which, if not banned, would contribute to the spread of venereal diseases.

By 1924, the cabarets and brothels in Pasay had become associated with trafficking in women and sexual slavery. In Pasay the distinction between dance hall, house of ill repute and cheap hotel seems to have become blurred. ${ }^{35}$ It is against this background of real and alleged abuses of women and moralist debates that Borromeo's vaudeville play 'Let's take a bath in Pasay' should be read. We find a vaudeville cast divided into distinct characters: the 'Moral Fanatic' represented the moralists who waged war against the modern institution of the dance hall and those who frequented it; 'The Modernist' and 'The Futurist" seemed to have represented those in favour of modern entertainment; 'the Life Saver' might have been a character symbolising the well-to-do dance hall or brothel patron who married a bailerina or prostitute and offered her a way out of the environments of ill repute and freedom from economic insecurity. ${ }^{36}$ Humour and the parodying of real debates and caricaturing those involved through the modern format of vaudeville was a way to deal with or to channel the anxieties about modernity itself in a way similar to cartoons in Philippine serials. Borromeo's show demonstrated rather than straightforwardly praised or criticised the debating sides. Politics and religion were generally avoided so as not to offend and alienate the conservative middle and upper-class patrons. Such short plays became a staple of Borromeo's vodavil. The successful format was quickly picked up by competing vaudeville troupes in Manila. ${ }^{37}$ Most of these local

34 A.J. Abalahin, 'Prostitution and the project of modernity: A comparative study of colonial Indonesia and the Philippines, 1850-1940' (Ph.D. dissertation, Cornell University, Ithaca, 2003), pp. 333-56.

35 Philippine Free Press, 12 July 1924; 16 and 23 Aug. 1924.

36 Manila Times, 16 Jan. 1924.

37 By late December 1925 five major companies made up the Manila vaudeville landscape: The Nifties based at the Savoy; the Variety Stars at the Rivoli; the Lux Peaches at the Lux Theater; and Borromeo Lou's Stadium Vod-A-Vil. The Midnight Revue was the only troupe with a dance hall as its permanent base: The Lerma. Alongside these 'permanent' companies short-lived vaudeville troupes were active throughout the 1920s and early 1930s, not to mention foreign companies who frequented Southeast Asia, including Manila. Among the latter we find, for instance, American vaudeville star Julian Eltinge and his All Star American Vaudeville and Jazz Band, but also artists like the native Hawaiian 
companies, consciously or not, chose the cinemas and theatres, rather than the dance halls, as their base of operation so as to disassociate themselves from the ill repute of the cabarets. Visiting foreign vaudeville companies played the theatres of Manila, the Grand Opera House being the main venue for vaudeville as well as opera.

In spite of promoting his music and shows as 'classy', in spite of his conservatism in dealing with politics and religion in his shows, and despite his middle to upperclass patronage, Borromeo could not entirely escape the stigma of the jazz age. In 1924, at the height of his artistic career and popularity across the Philippines, he and his many protégées were ignored completely in Raymundo Bañas' 1924 publication The music and theatre of the Filipino people. This was not a coincidental omission. Bañas emphasised and celebrated the achievements of a great number of Filipino actors, singers, composers and playwrights all actively engaged in Spanish and vernacular theatre and music. Jazz, whatever it meant to him, did not fit Bañas' ideal type of Philippine cultural nationalism in theatre and music. So, although many of his celebrated composers, like Francisco Santiago, also composed ragtime, and although some of the actors and playwrights cited were simultaneously heavily engaged in vaudeville, Bañas wrote such cultural crossovers out of what became a standard work on Philippine music and theatre. By 1932, it was difficult for Bañas to completely ignore jazz and Borromeo due to the latter's popularity across the archipelago. But this did not discourage Bañas from taking the opportunity once more to disqualify the 'King of Jazz' and his music. Confidently and in the past tense Bañas stated that 'Borromeo Lou [...] was once the jazz king in the Philippines. [.... The jazz music, [...], will not have a lasting life in the Philippines' ${ }^{38}$ At first glance these anti-jazz statements appear to fit the Sajonista-Hispano controversy explanatory model, but that would be overlooking Bañas' ambivalent relationship to modernity; nor should one infer that he necessarily opposed cosmopolitanism. His statements strongly suggest the emergence of a new and inclusive cultural nationalism rooted in a high-brow Hispano and European cultural musical and theatrical legacy, which by nature was highly cosmopolitan and perceived as modern. In this sense, and ironically so, Bañas' cultural vision showed far more similarity to Luis Borromeo's actual cultural background and practices than Bañas was able to recognise. While Bañas looked inward to inventing cultural tradition, Borromeo combined an outward cultural orientation with Filipino patriotism, creating vaudeville and music that justifies viewing him as a 'cosmopatriot'. ${ }^{39}$

In the early 1920s Borromeo's vaudeville had been received warmly by a group of leading Filipino politicians, intellectuals and artists, with whom he shared a similar social background and cosmopolitan orientation. By the late 1920s, however, this same elite seemed to lose its interest in vaudeville and became increasingly preoccupied with an essentialist cultural nationalism that problematised both modernity and cosmopolitanism.

musician, composer and impresario Ernest Kaai and his Hawaiian Troubadours. See the advertisements for these troupes in Manila Times, 6 Mar. 1920 and 28 Sept. 1922.

38 R.C. Bañas, 'The Tagalog theater and the future of our music', Music Lover, Jan. 1932, p. 11.

39 The term 'cosmopatriot' is borrowed from Edwin Jurriëns and Jeroen de Kloet, Cosmopatriots: On distant belongings and close encounters (Amsterdam: Rodopi, 2007). 
A similar narrative of a transforming and strained relation between cosmopolitanism, modernity and nationalism is found in the case of the Malay opera singeractress Miss Riboet who achieved stardom in Java in the late 1920s. She, however, operated in a far more politically polarised and racially segregated social environment compared to the Philippines under American rule.

\section{Miss Riboet: The singing newspaper}

In November 1925, starting with the city of Surabaya in East Java, Dutch and Sino-Malay newspapers in the Netherlands East Indies repeatedly referred to a new popular star who electrified audiences with her versatile acting, singing and dancing. By early 1930, the British, Sino-Malay and Malay press in colonial Malaya followed suit. Miss Riboet, as was her stage name, was born in 1900 to a Javanese family of humble origins. Her father was a soldier in the Netherlands East Indies Colonial Army (KNIL). She spent her childhood in the colonial army barracks (tangsi) without obtaining any formal education, the fate of many army children. In 1925 she married Tio Tek Djen, Jr, an educated and locally rooted Chinese (peranakan) from a well-to-do family from central Java who had straddled the gulf between journalism and running a small family-owned amusement park. In early 1942, after the Japanese had occupied Indonesia, Riboet and Tio would vanish almost as quickly and mysteriously from the stage as they had taken it in 1925.

Between 1925 and 1941, Riboet staged over more than a hundred different light opera plays in what must have been a dazzlingly, yet difficult to estimate, great number of performances spanning almost two decades, covering the main cities of the Netherlands East Indies and the Federated Malay States, the Straits Settlements, Borneo, and even Manila. Malay opera is the generic term for a form of theatre which by the 1920s shared many similarities with Filipino vodavil. Malay opera had evolved from two hybrid forms of theatre originating in the Malay peninsula, forms that by the 1910s were used interchangeably: bangsawan and komedie Stambul. Bangsawan had originated in the Straits Settlements in the late nineteenth century. Komedie Stambul was introduced at the turn of the century in the port city of Surabaya, East Java. ${ }^{40}$ By the turn of the twentieth-century bangsawan and Stambul companies exchanged actors, musicians, and theatrical, dance and musical repertoires, blurring the distinction between the two forms. Itinerant companies crossed the Strait of Malacca both ways. ${ }^{41}$ The central piece of a Malay opera show became a play: drama, musical or comedy. The sources for these plays were stories, often adapted from Arabian nights, European novels, Sino-Malay literature, Javanese theatre (wayang wong), Chinese opera and from the 1920s onward also from American (silent) movies. ${ }^{42}$ Malay opera introductions, intermissions or closing acts were known as 'extras'. These extras could include comedic sketches, vocal or

40 Tan, Bangsawan, pp. 16-18; Cohen, Komedie Stamboel, pp. 40-49.

41 Matthew I. Cohen, 'Border crossings: Bangsawan in the Netherlands Indies in the nineteenth and early twentieth centuries', Indonesia and the Malay world 30 (2002): 101-15.

42 Jedamski, ' $\ldots$ and then the lights went out', pp. 489, 492. See also Matthew I. Cohen, The Lontar anthology of Indonesia Drama: Plays for the popular stage (Jakarta: Lontar Foundation, 2010), pp. ixxiv. Unfortunately for the researcher, this latter introduction on theatre in colonial Indonesia does not include source references. 
instrumental music pieces, dances, acrobatics, or combinations of any of these, bringing this eclectic repertoire close to the vaudeville format.

Tio and Miss Riboet claimed to have modernised Stambul. They, however, were not the only ones to make such claims. Several contemporary Malay opera companies emphasised that they had introduced modern props, for example using electricity for spectacular lighting effects. Others, such as the Union Dahlia Opera, also explicitly claimed to offer a modernised Malay opera by staging realism in drama. ${ }^{43}$ This realism particularly concerned anxieties about modernity, such as newly-acquired wealth and social mobility through individual achievement. This is a recurrent theme in Orion's repertoire. One example is a play 'Oh Dad', which was performed several times in urban Java. The play was advertised as being based on an Indies novel containing: '[....] the outline of one's life full of realism, tragedy, satire and ... fresh humour'. 'Oh Dad!' is the story of how modern attitudes such as individualism pervade a family and eventually ruin its internal harmony. One family member dies of heartache, while another member takes his life, leaving the others in despair. ${ }^{44}$ Another example of a similar theme is found in the play 'Saidjah', in which a rural Javanese family fails to cope with their new wealth acquired by winning a lottery, ruining the family's happiness and harmony. ${ }^{45}$ In these plays Miss Riboet took the role of a mother who, against the odds, attempts to keep the family together. The role of the heroine fighting against the downside of modernity as well as those of tradition (i.e. Javanese feudalism and customs, adat, and peranakan Chinese institutions) are recurring roles and themes in Orion's dramatic repertoire. The drama Raden Adjeng Soemiatie, for instance, which in 1934 was reported to have been staged over two hundred times by Riboet, dealt with the troublesome relationship of a Javanese aristocrat and his Western-educated daughter who resists Javanese cultural conventions. ${ }^{46}$ This type of moral heroine addressing the ambiguities of modernity became one of Miss Riboet's favourite stage roles, along with the male impersonations for which she was repeatedly praised by the public. ${ }^{47}$ Spectators spanning diverse ethnic groups were drawn to these shows, and yet Miss Riboet became associated with particular socioeconomic strata: the 'European', peranakan Chinese, and Indonesian urban middle and upper classes. Of these groups, the local-born Chinese developed a special interest in and relationship with Malay opera in general and Riboet in particular.

The transformation from Stambul to modern Malay opera did not happen overnight, and a conventional approach to staging Malay opera was never entirely abandoned or lost. This is evident from the Surabaya debut. From November 1925 to February 1926, the company relied heavily on the tested Stambul and 'Chinese opera' formats in terms of repertoire and personnel. In short, nothing innovative can be detected at this point. What we see is that Tio and Riboet called for the services of experienced and famous performing artists. At this stage of her career Riboet was

43 Warna Warta, 14 Oct. 1927.

44 Bataviaasch Nieuwsblad, 1, 5 Aug. 1929.

45 Deli Courant, 9 Sept. 1929.

46 Radio, 15 Aug. 1934.

47 For similarities with the characters staged in Malay opera and those featured in 1910s Sino-Malay literature in relation to the issue of modernity, see Chandra, 'Women and modernity', pp. 4-6. 
not yet the prima donna she would become in the course of 1926, nor was Tio the playwright, director and stage manager he later claimed to be. ${ }^{48}$ For example, in Surabaya we find veteran Komedie Stambul director, playwright and actor-singer Willem Cramer, a Eurasian from the colonial capital Batavia, connected to the company. Cramer can be considered the first 'popular male stage star' in Java whose fame had been established through live performances and gramophone recordings of Stambul acts and keroncong songs released by the German gramophone company Odeon between the 1910s and 1925. ${ }^{49}$ Keroncong is a musical hybrid with origins in the nineteenth-century Eurasian community of Batavia. ${ }^{50}$ By the end of the second half of the 1920s, the gramophone industry showed an increasing interest in the genre, recruiting the winners of keroncong competitions to record their voices next to those of the available pool of anak wayang (Malay opera actors). One socially meaningful aspect of the keroncong contests which caused excitement and drew spectators was sindiran, a sung poetic joust in which the contestants used the Malay pantun style of quatrain verses to mock each other. ${ }^{51}$ It is on this oral literary and vocal tradition that Miss Riboet would build, creating a signature singing style: dongengan.

\section{'Jolly Jasz' and dongengan}

Miss Riboet performed and recorded keroncong on gramophone. Her song repertoire, however reveals a broader range of musical sources: Arabic music (masri), peranakan Chinese music, Javanese folk songs, Dutch folk songs, Malay songs then current in Sumatra and the Straits Settlements, and even a song claimed to be jazz. Her English song repertoire and the 'jolly jasz band' stand out as modern and cosmopolitan features, but the same can be said for the Arabic and Malay songs she performed. It is doubtful whether people in the Indies in the 1920s were concerned about the authenticity of the jazz or keroncong or that people drew clear lines between musical genres. It was only the middle to upper-classes, and this was a minority, who had access to jazz and jazz-related styles through gramophone recordings and live performances of touring Hawaiian, Filipino, British and Australian vaudeville artists who had performed in local theatres since the turn of the century. These artists presented their own interpretations of 'jazz' and related styles such as ragtime. Moreover, experimenting with styles, for example connecting keroncong to tango or Hawaiian music, was a common feature and typical of the jazz age in colonial Indonesia.

In the Netherlands East Indies, 'jazz' was certainly perceived as something modern and cosmopolitan, but not something exclusively or necessarily American. Due to the many professional Filipino artists who had toured the Netherlands East Indies and Malaya since the early twentieth century, jazz became strongly associated with Filipinos. It might thus not come as a surprise that in 1931 Miss Riboet proudly announced the inclusion of a 'Manila Cabaret' in her show. This group of Filipino

48 On aspects of individualism, gender and stardom as manifestations of modernity in Malay opera and Sino-Malay literature see Jedamski, ' $\ldots$ and then the lights went out', pp. 495, 497.

49 Sin Jit Po, 24 Nov. 1925.

50 Philip Yampolsky, 'Kroncong revisited: New evidence from old sources', Archipel 79 (2010): 7-56.

51 Peter Keppy, 'Keroncong, concours and crooners: Home grown entertainment in twentieth-century Batavia', in Linking destinies: Trade, towns and kin in Asian history, ed. Peter Boomgaard, Dick Kooiman and Henk Schulte Nordholt (Leiden: KITLV Press, 2008), pp. 143-4. 
vaudevillians performed their 'national songs' and dances in between scenes of a play. ${ }^{52}$ Filipinos were 'exporting' their cultural cosmopolitan-nationalism and Malay opera and Filipino vodavil proved perfectly compatible.

Apparently, Miss Riboet, her musicians and the majority of her audience had no direct access to the sources of Anglo-American jazz, either from gramophone records or live performances. Obviously, Miss Riboet was not deterred from appropriating jazz artistically and commercially. Her 78rpm discs labels and earliest advertisements in local newspapers promoted her band explicitly and consequently as a jazz orchestra, and some of the songs as 'jolly jasz'. ${ }^{53}$ Even the spelling of the word jazz, in this case 'jasz', itself remained open to interpretation. Such processes of differential readings of jazz is the kind of 'messiness' observed by Nicholas Evans in his study on American jazz:

[....] from World War I into the 1920s, the lines separating what we now call jazz, ragtime, Tin Pan Alley, vaudeville music, and other relevant forms were quite unclear. Moreover, the distinctions between 'authentic' jazz and its alleged commercial corruptions were seldom recognised. This lack of clarity was not due to a failure of analysis; rather, the current, rigorous differentiation of these musical forms is retrospective. The emergence of 'jazz,' as such, was a messy, uneven, discontinuous process that itself was unclear - then, if not also now. ${ }^{54}$

The adoption and local interpretation of modern and cosmopolitan musical styles such as jazz cannot, however, fully explain Miss Riboet's popularity nor that of Luis Borromeo. Her fame and contribution to Malay opera and popular music in colonial Indonesia and Malaya was due to her daring attitude to raising current social issues in a vocal satire and stage act that was reported as dongeng or dongengan. In this particular act Miss Riboet integrated three related Malay/Javanese oral literary traditions: pantun, sindiran and dongeng. Its significance goes beyond musical innovation. In Malay and Javanese dongeng stands for a tale, often with the supernatural as subject and an underlying moral lesson. Riboet replaced these vernacular tales of the supernatural with realism addressing local social issues in Malay and Javanese with a great deal of satire: the lack of sewerage and related sanitary troubles in a certain urban district; the wealth of estate owners against the poor living conditions of plantation coolies; or the hilarious characterisation of a Javanese cook who takes a taxi to the market to do the groceries. This latter song appears to have addressed the problem of rural Javanese dealing with modern urban life. Such topics dealing with realism through satire and parody hit a chord with both illiterate Indonesians (who were part of a vibrant oral culture), and even more with the inter-ethnic newspaper-reading middle-class audience. All had heard, read, were concerned about or at least aware of news about urban planning, hygiene, labour conditions, labour unrest, ethnic strife and so on as reported daily in the Dutch and Sino-Malay newspapers. Most of these literate spectators had a familiarity with or actually employed one or more

52 Bataviaasch Nieuwsblad, 29 Oct. 1931. These 'national songs and dances' were likely to be Hispano-Philippine music and dance forms like kundiman and jota.

53 De Locomotief, 22 June 1927.

54 Evans, Writing jazz, p. 14. 
Javanese domestic helpers as cleaners, cooks, gardeners, and babysitters, recruited from the vast reservoir of Javanese peasants. In the eyes of the spectators, the fact that Riboet was from humble Javanese origins made these dongeng authentic and legitimate. The European and Malay-speaking audience, including Eurasians, peranakan Chinese and Indonesian spectators, all enjoyed and highly appreciated the 'sung news'. The irony of it all was that Riboet herself could not read the newspapers. It was her husband who suggested the topics to her before the show. He picked them after having browsed through the local newspapers. Riboet would, on the spot, improvise pantun on the topic, an artistic quality that was little understood by Dutch newspaper reporters, who generally judged it as no more than funny singing. ${ }^{55}$

Dongengan would become Riboet's trademark, alongside her dramatic acting. Between 1927 and 1932, German record company Beka recorded an as yet-unidentified number of Miss Riboet's dongeng, helping to popularise her name. ${ }^{56}$ Musical satire had an equivalent in the common journalistic practice in the Netherlands East Indies of writing columns in which actual persons were named and insulted. Both of these practices were on the edge of what was socially acceptable and what the colonial authorities would tolerate, making both sung dongeng and the columns extremely exciting for the Malay opera spectators and the newspaper readership alike, two groups that overlapped. While there were numerous cases of journalists sentenced for crossing the lines acceptable to the colonial authorities, this seemed to rarely have happened to Miss Riboet or any other Malay opera actor, who developed a kind of self-censorship. In sum, Malay opera remained relatively protected from colonial intervention. From 1926 on, it was the Javanese ketoprak theatre, a style that seems to have been rejuvenated through the popularity of Malay opera, which became a target of the colonial authorities for its alleged subversive articulation of communism and Indonesian nationalism in allegorical plays. ${ }^{57}$

Miss Riboet's live appearances during her Surabaya debut left a deep impression on a young peranakan Chinese journalist in the city, Kwee Thiam Thjing. The peranakan Chinese formed a distinct group within the Chinese community, both politically and culturally. Formally, the local-born Chinese were treated by Dutch colonial legislation as 'Foreign Orientals' unless they applied for equal legal footing with Europeans. In the legal sense Foreign Orientals did not differ from Indonesian citizens, who were classified as 'natives', as both categories had to appear before the regular court of justice (landraad) in civil and criminal cases. From the 1910 onwards, under the influence of a burgeoning Chinese and Indonesian nationalism, this legal classification evoked debate among and between local-born and immigrant Chinese. These new nationalisms would divide both the ranks of peranakan Chinese and the new migrants (singkeh) into distinct groups with divergent political sympathies and loyalties. ${ }^{58}$ Inspired by Riboet, Kwee started composing and

55 De Javabode, 16 July 1928.

56 I thank Jaap Erkelens for giving me access to his private collection of $78 \mathrm{rpm}$ recordings and other materials. Drawing on his unpublished discographic data, Miss Riboet recorded approximately 140 songs for Beka between 1927 and 1932.

57 Harry A. Poeze, Politiek-politionele overzichten van Nederlandsch-Indië. Deel II 1929-1930 (Dordrecht: Foris, 1983), p. 5.

58 Leo Suryadinata, Peranakan Chinese politics in Java (Singapore: Singapore University Press, 1981). 
publishing dongeng himself in a Sino-Malay newspaper, Soeara Publiek, published in Surabaya, but with different content, including such topics as the social inequalities created and sustained by Dutch colonialism. Kwee showed great sympathy for a kind of Indonesian nationalism in which all citizens, regardless of their ethnic background, would enjoy equal rights. ${ }^{59} \mathrm{He}$ was particularly concerned with the local-born Chinese and their unequal legal and social position in colonial society. From his columns and poetry we can infer that Kwee was intrigued if not fascinated by Riboet. He envisaged her as a role model for the modern cosmopolitan Indonesian woman speaking out in public on social issues. In Kwee's eyes Riboet seemed capable of articulating a vision of an inclusive Indonesian nationalism that was compatible with modernity as well as cosmopolitanism. In April 1926 a dongeng, a form of Malay prose, entitled 'Als ik eens Miss Riboet was.... !" (If I were Miss Riboet.... !) appeared in Soeara Publiek. The poem can be read as a subversive political pamphlet, in which Kwee under his Malay pen name Tjamboek Berdoeri (Spiked Whip), questioned and ridiculed Dutch colonial rule in a similar vein to Miss Riboet's daring topical singing. In the light of this and his other columns written in Soeara Publiek between late 1925 and late 1927, the poem should be also read as Kwee's public confession to being a Miss Riboet fan. ${ }^{60}$

His satire, including published dongeng, a few dedicated to Riboet, did not remain without consequences. In January 1926, the colonial authorities charged Kwee for stirring hatred against the Dutch. He was sentenced and spent most of 1926 behind bars. ${ }^{61}$

Riboet's career followed a different trajectory. By 1934 she increasingly drew members of the European and Eurasian middle class and high-ranking Dutch officials and indigenous officials from the local aristocracy to her shows. These people had generally shown contempt for Malay opera as a cheap native imitation of European light opera; moreover, they displayed little sympathy with the various political and social aspirations of the peranakan Chinese and Indonesian nationalists. In October 1934, for example, on the opening night of Miss Riboet's show in the Hok Hoa theatre in the city of Medan, the urban node within East Sumatra's plantation belt, Malay newspaper Sinar Deli related: 'During the show we met the Governor [of Sumatra], Mayor [of Medan], the Sultan of Deli, Tengku Mahkota Deli, [and] some high officials from the circles of the Self-Governing Territories. [...] Many Europeans joined in to watch' ${ }^{62}$

In 1935, the board of the Bataviasche Schouwburg, the capital's municipally-owned theatre, allowed Miss Riboet and her company to perform for two nights. She was the first Malay opera star to be given this privilege. The Schouwburg was a temple of high art reserved for a mainly middle to upper class European audience who were shown European entertainment and Javanese performing arts. Although they were not commercial institutions, the municipally-owned

59 James Siegel in Kwee Thiam Tjing, Menjadi tjamboek berdoeri: Memoar Kwee Thiam Tjing (Depok: Komunitas Bambu, 2010), pp. xix, xxi, xxiii.

60 'Pridato hari Saptoe', Soeara Publiek, 5 Dec. 1925; 'Pridato hari Saptoe', Soeara Publiek, 24 Apr. 1926; 'Pridato hari Saptoe', Soeara Publiek, 6 Aug. 1927.

61 Kwee, Menjadi tjamboek berdoeri, p. 52.

62 Sinar Deli, 1 Nov. 1934. 
theatres shared similarities with colonial hotels in Southeast Asia. ${ }^{63}$ Both theatres and hotels were colonial spaces designed for leisure. The stone buildings with their neoclassical architecture were urban landmarks signifying cosmopolitanism as well as Empire. The ethnic composition of the clientele and, in the case of theatres, the exclusivist stage performance policies, reaffirmed European racial superiority. The Bataviasche Schouwburg board's policy was to book European drama, opera and classical music artists and Javanese court arts; Malay opera companies and ketoprak troupes were denied a stage. ${ }^{64}$ The Malay opera companies usually performed in tents and make-shift sheds. In Java these mobile venues were often situated at the alun-alun, the spacious squares adjacent to royal palaces (kraton). Other common commercial venues for Malay opera were cinemas and Chinese-owned theatres. The latter category especially was generally open to any kind of drama, music, or social activity, including political rallies. These venues, rather than the Schouwburg, were inter-ethnic 'contact zones', where Eurasians, peranakan Chinese, Javanese and members from other ethnic groups would interact. When it concerned Malay opera, race and class distinctions were far from lifted within these settings. Seats and ticket rates were classified according to race, largely following the legal distinctions between Europeans, Foreign Orientals and Natives. The best and most expensive seats were reserved for wealthy 'Europeans' and Chinese. The cheapest seats, often advertised as third or fourth class, were explicitly reserved for natives only, making the racial distinction and social hierarchy perfectly clear. ${ }^{65}$ Apart from this ethnic segregation, arguments and fights between spectators of different ethnic groups and even between performers and audience were common. One example took place during a show by Miss Inten's Malay Opera Company in its 1929 season in Semarang. One of the singer-actresses ridiculed some of the 'European' spectators using the stylised Malay form of sindiran. The Europeans targeted, most likely Eurasians who must have been fluent in Malay, took the ethnic stereotyping as an insult and responded verbally, disrupting the performance. The peranakan Chinese towkay who had hired the company publicly intervened, removed the artist from the stage, and prevented the conflict from escalating. ${ }^{66}$ Such social distinctions and ethnic tensions should make us seriously question assumptions about racial harmony within these multicultural settings. ${ }^{67}$

The shift from an inter-ethnic to a predominantly 'Dutch' spectatorship must have dashed Kwee's image of Riboet as cosmopolitan icon of an inclusive

63 Maurizio Peleggi, 'The social and material life of colonial hotels: Comfort zones as contact zones in British Colombo and Singapore, ca. 1870-1930', Journal of Social History 46, 1 (2012), pp. 124-53.

64 Nieuws dan den Dag van Nederlandsch-Indië, 2 Aug. 1935; Nieuws dan den Dag van Nederlandsch-Indië, 17 Aug. 1935. The Schouwburg's policy of excluding Malay Opera shows appears to have met its match with the policy of the board of the Victoria theatre in Singapore.

65 As for instance advertised by Miss Riboet's Orion Company during their season at the alun-alun of the city of Semarang in June 1927. Fourth-class seats were assigned to 'natives only' (boeat Boemipoetra sadja); Warna Warta, 9 June 1927. There is no evidence that this racial segregation was imposed by the authorities or by law.

66 Warna Warta, 4 Feb. 1929.

67 Jedamski, for instance, argues that Malay opera 'manifests an early expression of ethnic unification and an emerging notion of national identity [...]. Not only did the audience unite all different ethnic groups in mutual entertainment, but the actors, owners and producers also constituted a very mixed group'. Jedamski '.. and then the lights went out', p. 483. 
Indonesian nationalism and, in turn, also alienated her from Indonesian nationalists who wished to disassociate themselves from anything Dutch.

\section{The 'trinity' examined; genealogies compared}

Luis Borromeo and Miss Riboet contributed to home-grown entertainment in which modernity, cosmopolitanism and nationalism were conjoined. Their crosscultural experimentation, a 'messy' process in itself, caused debate and cultural confusion, especially among intellectuals, cultural purists, particularly cultural nationalists and moralists in both colonies. The term is conspicuously absent during the 1920s, yet Borromeo Lou and Miss Riboet could be considered to have pioneered what only after the Second World War became known as popular culture commercially-oriented entertainment for the masses. The fact that these artists appealed to the urban multiethnic middle class in both colonies makes the term 'masses' rather meaningless: popular culture was a middle-class phenomenon.

Vaudeville was not a standard package of American entertainment that was single-handedly imported into a cultural vacuum by a Cebuano who returned from the United States in 1921. Borromeo, with the help of others, built on an existing Hispano cultural repertoire of theatre and music created in the Philippines between the closing decades of Spanish rule and the 1910s. Fresh foreign sources from jazz to tango made him and his associates cultural cosmopolitans creating vaudeville Filipino-style. In this process vernacular theatre, European opera and vaudeville proved not to be artistically separate domains, nor were these entertainments necessarily in competition for audiences; interaction and exchange between these different artistic trades was common. There was certainly Sajonista-Hispano cultural tension. This tension did not, however, interfere with the dynamic cultural processes and transformations that occurred during the jazz age. Moreover, as an analytical tool this cultural divide cannot capture the complex relationship between modernity, cosmopolitanism and nationalism.

Artists infused their cultural products (drama, music) with socially relevant content that appealed to the mainly urban (inter-ethnic) upper to middle-classes. From his 1921 Cebu debut to his work in Manila in the mid-1920s, we can observe how Borromeo started to use vaudeville to address, or to use a possibly more appropriate term, register, local social concerns in plays. This innovation and development in vaudeville largely explains Borromeo's success and popularity in the Philippines. The social content of Borromeo's vaudeville together with his elitist orientation problematised the notion of vaudeville being a clear-cut expression of popular culture as escapist consumerism for the masses and as mere imitation of American vaudeville. $\mathrm{He}$ consciously targeted the Filipino middle to upper-classes, explicitly associating vaudeville and jazz with 'classiness', not with the masses per se. Borromeo also employed an (implicit) artistic hierarchy to distinguish himself as an exclusive artist with a classical music background.

Miss Riboet and her husband Tio Tek Djen, Jr, also appealed to a specific middle to upper-class audience, yet they themselves were reticent, even ambivalent, about their artistic achievements both in terms of social distinction and the audiences they wished to reach. Social critique also found its way into their Malay opera, through drama and a unique and much lauded feature of Miss Riboet's performances: topical singing 
(dongengan). Unlike Borromeo, Riboet was less conservative and cautious in registering what she and her husband perceived as social ills.

By patronising and sponsoring vodavil and Malay opera, or by speaking out publicly against it, or simply by ignoring it, specific individuals articulated social distinction as well as expressed their particular cosmopolitan-nationalist dreams. This process of defining and social positioning problematises notions of the 'popular'. While movement in social meaning is difficult to discern, it is possible to distil from Riboet's eclectic international play and song repertoire an inclusive cosmopolitan-nationalism. Riboet and Tio seldom used the term 'Indonesian' in relation to their plays or music. This avoidance was not simply a reaction to Dutch colonial hypersensitivity to Indonesian nationalism or a way to circumvent colonial censorship. It appears that Riboet and Tio were genuinely attracted to a kind of nationalism that would have included peranakan Chinese, Eurasian and Indonesian cultural elements, rather than an exclusive native Indonesian or Javanese nationalism. The multiculturalist ideal in Indonesia was not met, however, in the legal and political domain in the way inclusive Indonesian nationalists such as Kwee Thiam Thjing demanded. People like him posed a danger to the colonial status quo and were disciplined by the authorities. As in the early 1930s Miss Riboet was increasingly being appropriated by a 'European' middle-class audience and the colonial authorities, Kwee, like many other Indonesian nationalists, must have lost interest in Miss Riboet as a role model and voice of the colonised yearning for emancipation. By 1935, a 'Dutch' audience seems to have perceived Riboet as the embodiment of interracial harmony against the backdrop of growing ethnic polarisation and tension: she was a Javanese woman married to a peranakan Chinese; she displayed cultural diversity and versatility in her play, dance and song repertoire; she was sometimes a little daring, playing around with ethnic stereotypes in her songs and plays, but never posed a serious threat to Dutch racial superiority.

The acceptance of Miss Riboet by a primarily 'European' audience marks more than a shift in the ethnic composition of her spectatorship. It marks the problematic location of Malay opera in relation to racial and political loyalties. One could argue that Miss Riboet's political potency, at least as a potential supporter of Indonesian nationalism, evaporated as she came to be appreciated by a European middle class, the members of which clung to the colonial status quo. Borromeo Lou, being a member of the Filipino economic elite himself and being in proximity to the political elite, had undergone a similar process early on in his career. The modern as well as the cosmopolitan outlook of both vaudeville and Malay opera appealed to the urban middle class and elite, who unintentionally helped to 'discipline' or 'cleanse' these theatrical formats of anticolonial or subversive content. This should not lead us to view these cultural forms as harmless entertainment of little social significance without room for social criticism; instead we should recognise that complex processes of depoliticisation as well as empowerment were at work. These processes defined popular culture in a colonial context. It seems that historians working on Indonesia and the Philippines have found it difficult to see a meaningful connection between popular culture and such social processes. It might explain why Miss Riboet, in spite of her status as popular star during the colonial period, sank into almost complete oblivion in Indonesian historiography. 
Luis Borromeo has not descended to complete oblivion in the Philippines, but a similar tendency to underrate the social and cultural meaning of vaudeville can be detected in 'consumer escapist' explanations of the popularity of the format. Due to Nick Joaquin's eloquently written and inspiring popular histories, Borromeo is remembered as a Filipino icon of popular culture during the American period. The equation of the 'popular' with the American period, however, tends to disconnect Borromeo and his many artistic contemporaries from the sociocultural environment that they were part of and which they were transforming at the same time: the Filipinised Hispano cultural legacy in music and theatre.

Borromeo and Riboet, each in their own particular way, expressed a cosmopolitan, modern and nationalist spirit, and equally articulated anxieties about these same elusive phenomena. Such ambiguities and contradictions should be taken into account in the study of popular culture in a colonial context. Obviously, for some contemporaries, like Filipino cultural nationalist Bañas, vaudeville and jazz had been suspect foreign expressions from the start, making even these 'antimodernists' children of the jazz age. 